\title{
Serological diagnosis of congenital toxoplasmosis
}

\author{
K. A. KARIM AND G. B. LUDLAM \\ From the Regional Public Health Laboratory, Leeds
}

SYNOPSIS A comparison of the indirect haemagglutination test (IHAT) with the dye test (DT) in 23 infants with congenital toxoplasmosis showed that in the early part of the first year of life the IHAT titres were nearly all lower than the DT titres. In six cases the IHAT was negative or the titre was so low that the cases could have been missed in routine screening. Later in the first year the IHAT titres became higher than the DT and remained so. The infants belonging to mothers with a high IHAT and therefore assumed to have become infected early in pregnancy had severe infections which included all the cases of hydrocephalus. Infants of mothers with low IHAT titres relative to the DT and therefore thought to have been infected later in pregnancy had generalized, mild or subclinical infection. With some difficulty a suitable commercial conjugated anti-IgM serum was found that gave positive results in immunofluorescent antibody tests for specific IgM antibody with all the infected infants and their mothers throughout the first year and negative results in uninfected infants and their mothers.

Our recent comparisons between the antibody titres obtained by various techniques in glandular and ocular toxoplasmosis (Karim and Ludlam, 1975) have been extended to congenital toxoplasmosis, a disease in which diagnosis is often difficult. The indirect haemagglutination test (IHAT) and the immunofluorescent antibody test for specific IgM antibody (IgM-IFAT) have produced results which it is hoped will be useful in diagnosis.

\section{Materials and Methods}

One hundred and thirty-eight sera from 66 infants were selected for this study on the grounds of suspected congenital toxoplasmosis and the presence of dye test (DT) titres higher than those found commonly in the normal population. Ninety-four sera were also obtained from their mothers at about the same time. Sera obtained repeatedly from some patients made the construction of antibody production curves possible.

Details of the techniques used in the DT, IHAT, and IgM-IFAT have already been reported (Karim and Ludlam, 1975). A satisfactory conjugated anti-IgM serum from Nordic Diagnostics, batch No. 1071, was used in the IgM-IFAT with Evans Blue (1 in 5000) as counterstain.

Received for publication 25 November 1974.

\section{Results}

It was possible to divide the 65 infants into two groups-23 regarded as infected on the grounds of an initial IgM-IFAT titre of $1 / 32$ or greater, after excluding cases of placental leak by testing for specific IgA antibody (Miller, Sunshine, and Remington, 1969), and the persistence of antibody as shown by other tests in the latter part of the first

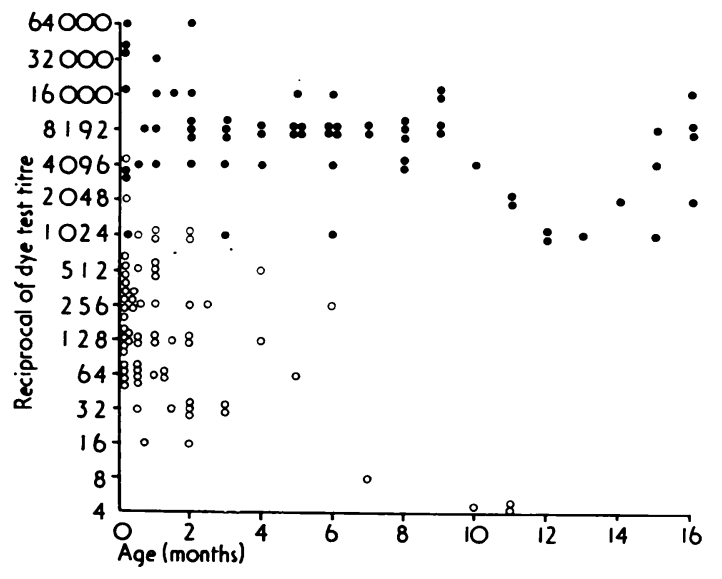

Fig 1 Dye test titres at various ages in infants with congenital toxoplasmosis $(O)$ and uninfected infants $(O)$. 
Fig 2 Indirect haemagglutination test titres at various ages in infants with congenital toxoplasmosis $(\bullet)$ and uninfected infants $(\bigcirc)$.

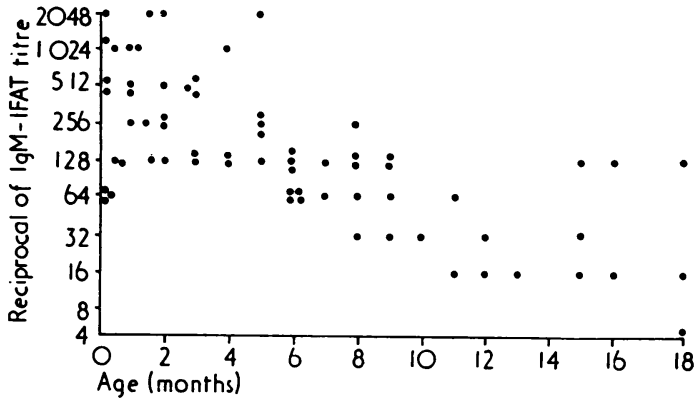

Fig 3 IgM-IFAT titres at various ages in infants with congenital toxoplasmosis.

year; and an uninfected group of 43 in which the IgM-IFAT titre was less than $1 / 8$ and in which the other antibodies present in the first half of the first year had gradually disappeared.

\begin{tabular}{|c|c|c|c|c|c|c|c|c|}
\hline \multirow[t]{2}{*}{ Case } & \multirow[t]{2}{*}{ Infant's Age (yr) } & \multirow[t]{2}{*}{ Clinical Notes } & \multicolumn{3}{|c|}{ Infant's Serology } & \multicolumn{3}{|c|}{ Mother's Serology } \\
\hline & & & $D T$ & $I H A T$ & $\operatorname{Ig} M-I F A T$ & $D T$ & $I H A T$ & $\operatorname{Ig} M-I F A T$ \\
\hline \multicolumn{9}{|c|}{ A. Mother's IHAT titre $>D T$ titre } \\
\hline 1 & $5 / 12$ & $\begin{array}{l}\text { Hydrocephalus, intracranial } \\
\text { calcification, splenomegaly }\end{array}$ & 4096 & 64 & 256 & 1024 & 4096 & 64 \\
\hline 2 & $4 / 12$ & $\begin{array}{l}\text { Hydrocephalus, intracranial } \\
\text { calcification, splenomegaly }\end{array}$ & 4096 & 128 & 1024 & 2048 & 8192 & 128 \\
\hline 3 & $10 / 12$ & Choroiditis & 4096 & 4096 & 32 & 1024 & 8192 & 128 \\
\hline 4 & $5 / 12$ & Uveitis & 8192 & 1024 & 2048 & 1024 & 8192 & 64 \\
\hline 5 & $2 / 365$ & Rash, enlarged spleen & 16000 & 8192 & 256 & 8192 & 8192 & 1024 \\
\hline 6 & $7 / 52$ & Enlarged spleen & 8192 & $<8$ & 2048 & 8192 & 8192 & 64 \\
\hline 7 & $8 / 12$ & $\begin{array}{l}\text { Hydrocephalus, intracranial } \\
\text { calcification, splenomegaly }\end{array}$ & 4096 & 16000 & 32 & 2048 & 2048 & 32 \\
\hline 8 & $2 / 365$ & $\begin{array}{l}\text { Hydrocephalus, intracranial } \\
\text { calcification, hepatosplenomegaly } \\
\text { Mother had lymphadenopathy at } \\
8 \text { weeks' pregnancy }\end{array}$ & 32000 & 64000 & 512 & 8192 & 32000 & 64 \\
\hline 9 & $12 / 12$ & Retinal abnormalities & 1024 & 2048 & 16 & 512 & 4096 & $<8$ \\
\hline 10 & $11 / 365$ & $\begin{array}{l}\text { Hydrocephalus, intracranial } \\
\text { calcification, splenomegaly }\end{array}$ & 4096 & 32000 & 64 & 32000 & 64000 & 256 \\
\hline 11 & $16 / 12$ & Choroiditis & 8192 & 64000 & 128 & 2048 & 4096 & 32 \\
\hline 12 & $3 / 52$ & $\begin{array}{l}\text { Hepatosplenomegaly, retinopathy, } \\
\text { thrombocytopenia }\end{array}$ & 8192 & 4096 & 512 & 8192 & 8192 & 128 \\
\hline 13 & $2 / 365$ & Hepatosplenomegaly, PUO, purpura & 1024 & 1024 & 64 & 2048 & 2048 & 32 \\
\hline 14 & $11 / 12$ & $\begin{array}{l}\text { Hydrocephalus at } 5 / 12 \text {, intracranial } \\
\text { calcification }\end{array}$ & 2048 & 8192 & 64 & 512 & 2048 & $<8$ \\
\hline \multirow[t]{2}{*}{15} & $2 / 365$ & $\begin{array}{l}\text { Enlarged spleen, rash } \\
\text { At } 12 \text { months child well }\end{array}$ & 4096 & 512 & 512 & 2048 & 2048 & 32 \\
\hline & \multicolumn{8}{|c|}{ B. Mother's IHAT titre $<D T$ titre } \\
\hline 1 & $1 / 52$ & Prolonged jaundice; squint later & 32000 & 128 & 1024 & 32000 & 128 & 128 \\
\hline 2 & $3 / 12$ & $\begin{array}{l}\text { Baby asymptomatic } \\
\text { Mother had lymphadenopathy at } \\
34 \text { weeks' pregnancy }\end{array}$ & 4096 & 1024 & 512 & 8192 & 256 & 128 \\
\hline 3 & $5 / 52$ & $\begin{array}{l}\text { Baby well first } 2 \text { weeks of life, } \\
\text { then convulsions }\end{array}$ & 32000 & 2048 & 1024 & 16000 & 1024 & 256 \\
\hline 4) & $3 / 12$ & Twins : failure to thrive; asymptomatic & 1024 & 64 & 512 & 8192 & 1024 & 64 \\
\hline 5) & $6 / 12$ & $\begin{array}{l}\text { Mother had illness last month } \\
\text { of pregnancy }\end{array}$ & 8192 & 512 & 128 & 一 & 一 & 一 \\
\hline 6 & $2 / 12$ & $\begin{array}{l}\text { Spleen enlargement } \\
\text { Mother had illness last month of } \\
\text { pregnancy }\end{array}$ & 4096 & 512 & 256 & 4096 & 256 & 256 \\
\hline 7 & $3 / 365$ & Spleen enlargement & 64000 & 32 & 64 & 64000 & 2048 & 1024 \\
\hline 8 & $6 / 52$ & Neonatal hepatitis; jaundice & 16000 & $<8$ & 256 & 33000 & 2048 & 2048 \\
\hline
\end{tabular}

Table I Serological results in first sera from mothers and their infants with congenital toxoplasmosis 
Figure 1 shows that the DT titres of the infected infants were already high in the first 2 months, geometric mean (GM) $1 / 10790$, and that the high titres persisted for at least 18 months. In the uninfected group the GM of the DTs in the first 2 months was $1 / 173$ and this fell steadily, running at a lower level than that of the infected group and eventually becoming negative well before the end of the first year. With five exceptions, in each of which the child followed a sibling with congenital infection, all the uninfected children had initial DT titres of $1 / 1024$ or less. In the infected group three had an initial titre of $1 / 1024$, the rest $1 / 4096$ or higher.

The IHAT titres (fig 2) showed a wide scatter in both the infected and uninfected groups, especially in the first 2 months. In fact the GM of the IHAT titres for that period was only $1 / 308$ in the infected infants, distinctly lower than in the uninfected infants in whom the GM was $1 / 1200$. Antibody in the uninfected group had a half-life of roughly one month and had reached undetectable levels by month 10 (cf. DT titres). The infected cases showed a rise in the IHAT titre to a high level in the latter part of the year, and this was maintained as in the DT.

The IgM-IFAT titres were scattered in the first 2 months in the infected infants (fig 3), tended to peak between 2 and 4 months, and then declined over the rest of the year without becoming negative. Table I shows that IgM was present in the sera of all the mothers of infected infants except in the sera of two mothers with infants 11 and 12 months old. The IgM-IFAT test was never positive in the uninfected group.

Figure 4 shows the characteristic antibody curves for the three tests over the first 15 months of life in an infant who had prolonged neonatal jaundice followed by a squint several months later. The serological results were not materially different on testing at 3 years and still showed the maintained high levels of DT and IHAT with a negligible IgM-IFAT titre.

The infected infants with their mothers were divided into two groups: in one the mothers' IHAT titres were equal to or greater than the DT (table IA); in the other the IHAT titre was less than the DT (table IB). The table also shows the IgM-IFAT results for the mothers and infants and summarizes the clinical findings in the infants. The findings in the suspected but uninfected infants were: jaundice 14 cases, microcephaly 2 , rash 6 , neurological disorder 5 , hydrocephalus 3 , history of previously infected sibling 8 , hepatosplenomegaly 1 , myocarditis 2 , bilateral corneal opacity 1 , and one twin whose partner was infected.

The mothers of infected infants had a GM of $1 / 5780$ in the DT and a GM of $1 / 2890$ in the IHAT; the mothers of uninfected infants showed GMs of $1 / 240$ and $1 / 2560$ respectively.

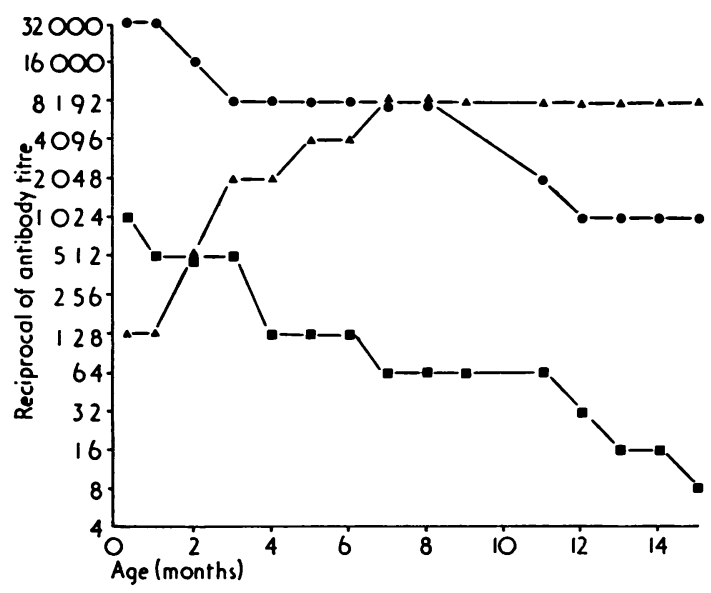

Fig 4 Antibody titres in a case of congenital toxoplasmosis - dye test; $\triangle$ IHAT; IgM-IFAT.

\begin{tabular}{|c|c|c|c|c|c|c|c|c|c|c|}
\hline \multirow[b]{2}{*}{ Case } & \multirow{2}{*}{$\begin{array}{l}\text { Age } \\
(m t h)\end{array}$} & \multicolumn{3}{|c|}{ Mother } & \multicolumn{3}{|c|}{ Twin I } & \multicolumn{3}{|c|}{ Twin II } \\
\hline & & $D T$ & $I H A T$ & $\operatorname{Ig} M-I F A T$ & $D T$ & $I H A T$ & $I g M-I F A T$ & $D T$ & $I H A T$ & $I g M-I F A T$ \\
\hline $\begin{array}{l}\text { EDW } \\
\text { (twin I infected } \\
\text { twin II uninfected) }\end{array}$ & $\begin{array}{l}\frac{1}{2} \\
3 \\
6\end{array}$ & $\begin{array}{l}8192 \\
8192 \\
4096\end{array}$ & $\begin{array}{r}4096 \\
8192 \\
16000\end{array}$ & $\begin{array}{l}64 \\
32 \\
32\end{array}$ & $\begin{array}{l}8192 \\
8192 \\
8192\end{array}$ & $\begin{array}{r}<8 \\
8 \\
1024\end{array}$ & $\begin{array}{r}2048 \\
256 \\
64\end{array}$ & $\begin{array}{r}1024 \\
256 \\
256\end{array}$ & $\begin{array}{l}32 \\
32 \\
16\end{array}$ & $\begin{array}{l}<8 \\
<8 \\
<8\end{array}$ \\
\hline $\begin{array}{l}\text { Dow } \\
\text { (both infected) }\end{array}$ & $\begin{array}{r}3 \\
6 \\
7 \\
15 \\
22\end{array}$ & $\begin{array}{l}\overline{8192} \\
\overline{-} \\
-\end{array}$ & $\begin{array}{l}\bar{z}^{2048} \\
\overline{-}\end{array}$ & $\begin{array}{l}\overline{64} \\
- \\
-\end{array}$ & $\begin{array}{r}1024 \\
1024 \\
4096 \\
4096 \\
256\end{array}$ & $\begin{array}{r}64 \\
64 \\
128 \\
4096 \\
8192\end{array}$ & $\begin{array}{r}512 \\
64 \\
128 \\
32 \\
<8\end{array}$ & $\begin{array}{l}-\overline{8192} \\
8192 \\
2048 \\
4096\end{array}$ & $\begin{array}{r}- \\
512 \\
512 \\
1024 \\
-\end{array}$ & $\begin{array}{c}\overline{128} \\
128 \\
16 \\
-\end{array}$ \\
\hline $\begin{array}{l}\text { MCL } \\
\text { (both uninfected) }\end{array}$ & $\begin{array}{r}\frac{1}{2} \\
2 \\
11\end{array}$ & $\begin{array}{l}512 \\
512 \\
256\end{array}$ & $\begin{array}{l}16000 \\
32000 \\
16000\end{array}$ & $\begin{array}{l}<8 \\
<8 \\
<8\end{array}$ & $\begin{array}{r}512 \\
128 \\
<8\end{array}$ & $\begin{array}{r}8192 \\
16000 \\
<8\end{array}$ & $\begin{array}{l}<8 \\
<8 \\
<8\end{array}$ & $\begin{array}{r}128 \\
32 \\
<8\end{array}$ & $\begin{array}{r}4096 \\
4096 \\
<8\end{array}$ & $\begin{array}{l}<8 \\
<8 \\
<8\end{array}$ \\
\hline
\end{tabular}

Table II Serological results in mothers and twins suspected of congenital toxoplasmosis 
The results of tests on three sets of twins are shown in table II and demonstrate the typical antibody results found in both infected and uninfected infants and their mothers. The EDW twins, both girls, were born at 34 weeks. The infected one was well at birth except for an enlarged spleen and jaundice by the third day, and her haemoglobin fell to $57 \%$ in two to three weeks. At 6 weeks some pigmented chorioretinitis was found and on the results of her serological tests she was put on pyrimethamine (daraprim) for 12 days and on sulphadiazine for three weeks. At $5 \frac{1}{2}$ months she was well and the spleen was not palpable. Her twin sister was well all the time and her tests showed her to be uninfected. The serum of one of the DOW twins was first tested and found to be positive at 3 months because of failure to thrive. Later the serum of the second twin was found to give a positive DT of 1/8192 and this persisted, indicating infection, but the twin remained asymptomatic. Twins MCL both had a rash for a few days after birth and one had a haemoglobin of $200 \%$ at birth. They both had raised DT titres but a negative IgM result; the gradual loss of other toxoplasma antibodies showed them to be free from infection.

\section{Discussion}

Our preliminary work with the IgM-IFAT yielded entirely negative results in infants shown by the persistence of other toxoplasma antibodies through the first year of life to be cases of congenital infection. However, Remington, Miller, and Brownlee (1968 a, b), who had been responsible for the early advocacy of this test for determining the presence of specific $\operatorname{IgM}$, have reported that many batches of conjugated anti-IgM sera, although reacting with adult sera, give false negative results in infected infants. We therefore tested a variety of commercial antisera and eventually obtained one giving positive results with all our infected infants and negative results in infants shown by the gradual loss of antibody to be uninfected, and this batch was used for all our work. Since then Remington and Desmonts (1973) have found some anti-IgM sera giving false positive results in uninfected infants with high titre passive antibody and other sera which, although apparently satisfactory, did not detect specific IgM in certain cases of infection in the early months of life, although the antibody was demonstrated later in the year. We have not met this phenomenon, but we have had only two cases of subclinical infection, and it may be that IgM negative cases are more likely to be subclinical. It appears however that a negative IgM result in the first few months does not entirely rule out congenital toxoplasmosis.
Specific IgM was found in all the mothers of infected infants in the first 10 months and was absent $\%$ from the mothers of uninfected infants, with the $\overrightarrow{\vec{F}}$ exception of five mothers, each of whom had had an? infected infant in a previous pregnancy. In all five, 듬 IgM was present at the end of the pregnancy $\overline{\bar{c}}$. following the infected one and also in a further $\overrightarrow{\widehat{D}}$ pregnancy in one mother. In none of these subsequent $\frac{}{q}$ pregnancies was an infected infant produced. The IHAT titres in these mothers were very high, $\overrightarrow{0}$ suggesting that in spite of the IgM result the mother's $\overrightarrow{-}$ infection was not recent.

A study of the DT and IHAT titres shows that the DT titres were consistently high in the infected? infants in the first 2 months (GM 1/10 790) and $\infty$ were maintained at a persistently high level, whereas ${ }_{\omega}^{c}$ in the uninfected group the titres started at a lower level (GM 1/173) and then gradually fell to negative. By contrast the IHAT titres initially varied over $a_{-}$ wide range, but the titre in the infected infants rose $\bar{z}$ to a high level by 6 months and began to exceed the DT titre after this time; the titres in the uninfected $\vec{c}$ group showed the expected decline over the same of period (fig 1).

There was an initial drop in the IHAT titre in some cases, followed by a rise (table II DOW). This may have been due to loss of passive antibodyo followed by a rise due to the infant's own production of antibody. This fall was not found in the DT, $\stackrel{\mathbb{Q}}{2}$ probably due to the earlier production of active $\overrightarrow{\vec{O}}$ high titre DT antibody.

As expected from earlier work (Karim and Ludlam, 1975), the majority of infected infants under? 6 months had an IHAT titre less than the DT (37) sera out of 40), but in 27 sera tested after 6 months? the IHAT titre was greater than or equal to the DT 3 in 24. The most important feature of these findings was that in two cases the IHAT titre was negative $\frac{3}{3}$ at $1 / 8$ and in four the IHAT titres ranged from $1 / 32$ to $1 / 128$. The DT titres in these cases ranged from 5 $1 / 1024$ to $1 / 64000$. This shows that these six cases $\frac{D}{0}$ could well have been missed if the IHAT alone had been used for screening. Nevertheless the combined $N$ IHAT and DT can be useful, since a low IHAT result with a high DT result suggests recent infection in the mother and therefore increases the probability ${ }_{0}^{\omega}$ that the infant is infected.

The mothers of infected infants had higher DT titres (GM 1/5780) than the mothers of the uninfected (GM 1/240) but the GM of the IHAT titres:of the two groups was about the same, a GM of $\frac{0}{0}$ $1 / 2890$ in the mothers of the infected infants and $\overrightarrow{\mathbb{D}}$ $1 / 2560$ in the mothers of the uninfected. A high $\frac{O}{\mathbb{Q}}$ IHAT titre with a lower DT titre combined with a negative IgM result in the uninfected mothers? suggested that they had been infected at least $18 \AA$ 
months earlier. On the other hand, IHAT titres less than the DT in mothers of infected infants suggested that infection had occurred in the latter half of pregnancy.

Sabin, Eichenwald, Feldman, and Jacobs (1952) ascribed severe cases of congenital toxoplasmosis to infection in early pregnancy, later infections being more generalized and less likely to involve the central nervous system. Eichenwald (1959), using the CFT, positive results from which he regarded as indicative of recent infection, supported these findings, concluding that central nervous system involvement was more characteristic of early infections and that later ones were more generalized (jaundice, splenomegaly, fever, etc.). The more recent work of Desmonts and Couvreur (1974 a, b) agreed with this and indicated that although mild or subclinical infections could result from early infection the great majority followed infection late in pregnancy. Some of these subclinical infections became manifest only after months or years; others showed no detectable abnormality after many years of follow-up.

Our findings support the above reports. In table IA are grouped all the mothers with IHAT titres equal to or greater than the DT titres, where one would therefore expect infection to have occurred early in pregnancy. The 15 children of these pregnancies consisted of six with hydrocephalus, five with eye conditions, and four with splenomegaly. On the other hand, table IB contains seven mothers (with eight infants) with relatively low IHAT titres. Two of these infants had splenomegaly, one fits at 2 weeks, two neonatal jaundice (one with squint later), one showed failure to thrive, and two were symptomless at 3 months. These two groups correspond closely clinically to the early and later cases described by the earlier workers.

Positive specific IgM in the young infant establishes the diagnosis of congenital toxoplasmosis, assuming a satisfactory anti-IgM serum is in use. The main problem is the type of case described by Remington and Desmonts (1973) where specific IgM is undetectable. In such a case serological findings favouring a diagnosis of congenital toxoplasmosis in the young infant would be a DT result of $1 / 1024$ or higher, an IHAT titre distinctly less than the DT titre in the infant, and a positive IgM result in the mother. Where the IHAT approximates to the DT titre there may have been infection early in pregnancy and here one would expect a severe form of the disease. With the above serological findings, especially if accompanied by a suggestive clinical picture, specific chemotherapy should be considered and, to confirm the tentative diagnosis, the infant's sera should be tested at intervals for the appearance of specific IgM and to see whether the other antibody levels are maintained.

We wish to thank the pathologists and clinicians in various parts of the country who have so willingly supplied us with sera and clinical information, and Professor G. Gowland for his advice and support in carrying out this investigation.

\section{References}

Desmonts, G. and Couvreur, J. (1974a). Congenital toxoplasmosis: a prospective study of 378 pregnancies. New Engl. J. Med., 290, 1110-1116.

Desmonts, G. and Couvreur, J. (1974b). Toxoplasmosis in pregnancy and its transmission to the fetus. Bull. N.Y. Acad. Med., 50, 146-159.

Eichenwald, H. F. (1959). A study of congenital toxoplasmosis. In Human Toxoplasmosis, edited by J. C. Siim, pp. 41-49. Munksgaard, Copenhagen.

Karim, K. A. and Ludlam, G. B. (1975). The relationship and significance of antibody titres as determined by various serological methods in glandular and ocular toxoplasmosis. J. clin. Path., 28, 42-49.

Miller, M. J., Sunshine, P. J., and Remington, J. S. (1969). Quantitation of cord serum IgM and IgA as a screening procedure to detect congenital infection: results in 5,006 infants. J. Pediat., 75, 1287-1291.

Remington, J. S. and Desmonts, G. (1973). Congenital toxoplasmosis: variability in the IgM-fluorescent antibody response and some pitfalls in diagnosis. J. Pediat., 83, 27-30.

Remington, J. S., Miller, M. J., and Brownlee, I. (1968a). IgM antibodies in acute toxoplasmosis. I. Diagnostic significance in congenital cases and a method for their rapid demonstration. Pediatrics, 41, 1082-1091.

Remington, J. S., Miller, M. J., and Brownlee, I. (1968b) IgM antibodies in acute toxoplasmosis. II. Prevalence and significance in acquired cases. J.Lab.clin. Med., 71, 855 866.

Sabin, A. B., Eichenwald, H., Feldman, H. A., and Jacobs, L. (1952). Present status of clinical manifestations of toxoplasmosis in man: indications and provisions for routine serological diagnosis. J. Amer. med. Ass., 150, 1063-1069. 